\title{
CORNEAL EPITHELIAL INCLUSION CYST IN A DOG
}

\author{
CISTO DE INCLUSÃO EPITELIAL CORNEANO EM CÃO
}

\author{
Carla de Freitas Campos ${ }^{1}$, Ivia Carmem Talieri ${ }^{1}$, \\ Felipe Antônio Mendes Vicenti ${ }^{1}$ and José Luiz Laus ${ }^{2}$
}

\section{SUMMARY}

An unilateral corneal epithelial inclusion cyst in a 7 year-old male Boxer dog is reported. The cyst had been observed for thirty days, was unique, not congenital and only one eye was involved. Seven months prior to the referral the dog had manifested indolent corneal ulcer treated with grade keratotomy and third eyelid flap. The cyst was removed by superficial keratectomy followed by a conjunctival pedicle graft. Recovery was uncomplicated and there wasn't recurrence seven months after the surgery.

Key words: ophthalmology, eye, stroma.

\section{RESUMO}

Relata-se o caso de um cisto de inclusão epitelial em um cão macho, boxer, com 7 anos de idade. $O$ cisto havia sido observado por trinta dias, era único, não congênito e apenas um olho estava acometido. Sete meses antes da consulta, o cão apresentou ulceração corneana indolente, tratada com ceratectomia e recobrimento de terceira pálpebra. $O$ cisto foi removido através de ceratectomia superficial, seguida de enxerto conjuntival pediculado. A recuperação foi descomplicada e não houve recidiva após sete meses de pós-operatório.

Palavras-chave: oftalmologia, olho, estroma.

\section{INTRODUCTION}

This study aimed to report a case of corneal epithelial inclusion cyst, which has not been frequently reported in dogs. It was first reported in four dogs in 1974 (KOCH et al., 1974). One of them had previously manifested corneal ulcer treated with third eyelid flap in the site of the cyst formation. The others did not present prior corneal lesion. In 1976, a cyst formation three and a half years after a keratectomy was recorded (SCHMIDT \& PRASSE, 1976). In 1990, 16 were recorded. Among these, eleven had presented corneal ulcer or trauma before the cyst formation while the others had not presented any previous lesions (BEDFORD et al., 1990). The etiology remains uncertain but keratotomies (JESTER $\boldsymbol{e t}$ al., 1983), epikeratoplasties (AIRAJHI \& AIKHARASHI, 1996), corneal epithelium distrophies with recurrent erosions (FRANÇOIS, 1978; TABERY \& HOLM, 1987) have been hypothesized as possible origins for man. It is considered a benign entity, but sight may be impaired as consequence to its size and localization. It is an important differential diagnosis of neoplasia, dermoids, bullous keratopathy and staphyloma formation (BEDFORD et al., 1990). The lumen is limited by non-keratinized squamous epithelium, filled with a serous fluid of variable coloration and cellular content (KOCH et al., 1974; SCHMIDT \& PRASSE, 1976; BEDFORD et al., 1990). The cysts formation might be due to trappment of the epithelial cells into the stroma, with consequent cellular proliferation and accumulation of secretion and desquamated material (BEDFORD, 1997).

Treatment of epithelial inclusion cysts in man has included aspiration, cauterization, and excision of the anterior wall. Because astigmatism is not of primary concern in the dog, keratectomy has been preferred (KOCH et al., 1974).

\footnotetext{
${ }^{1}$ DVM, MSc., Faculdade de Ciências Agrárias e Veterinárias (FCAV), Universidade Estadual Paulista (UNESP), Jaboticabal, São Paulo, Brasil.

${ }^{2}$ DVM, MSc., PhD., FCAV, UNESP, Jaboticabal. Departamento de Clínica e Cirurgia Veterinária. Author for correspondence, Via de Acesso Professor Paulo Donato Castellane, s/n, 14870-000, Jaboticabal - São Paulo, Brasil. E-mail: jllaus@ fcav.unesp.br. 


\section{DESCRIPTION OF THE CASE}

A 7-year-old male boxer dog was referred for a corneal cystic formation at the Ophthalmology Service of Governador Laudo Natel Veterinary Hospital - FCAV/UNESP Jaboticabal. The owner reported an evolution of thirty days and no signs of discomfort. The clinical examination revealed mild opacification and vascularization on and around the cyst, which was localized on the superotemporal quadrant of the right cornea (Figure 1). It was four millimeters of diameter and two high. The bulbar conjunctiva was mildly congested and no discharge was observed. The Schirmer Tear Test $\mathrm{I}^{\mathrm{a}}$ and the applanation tonometry ${ }^{\mathrm{b}}$ presented normal values and the fluorescein dye test ${ }^{\mathrm{c}}$ was negative. Blepharospasm and photophobia were not present. The slit lamp ${ }^{\mathrm{d}}$ examination showed involvement of the epithelium and upper stroma and a fluid filled lumen.

The cyst was removed by superficial keratectomy and a conjunctival pedicle flap was made (Figure 2). In an attempt to avoid secondary infections, the dog was treated with topical antibiotics (Tobramycin sulphate) ${ }^{\mathrm{e}}$ for eight days postsurgically.

Considering the condition of corneal dystrophy, the dog was examined weekly and forty days after the surgery the pedicle was transected. Healing occurred as noted by the corneal remodeling four months after the surgery (Figure 3). No other treatment measures were taken.

\section{DISCUSSION}

It has been reported that corneal cysts may have a traumatic or congenital origin

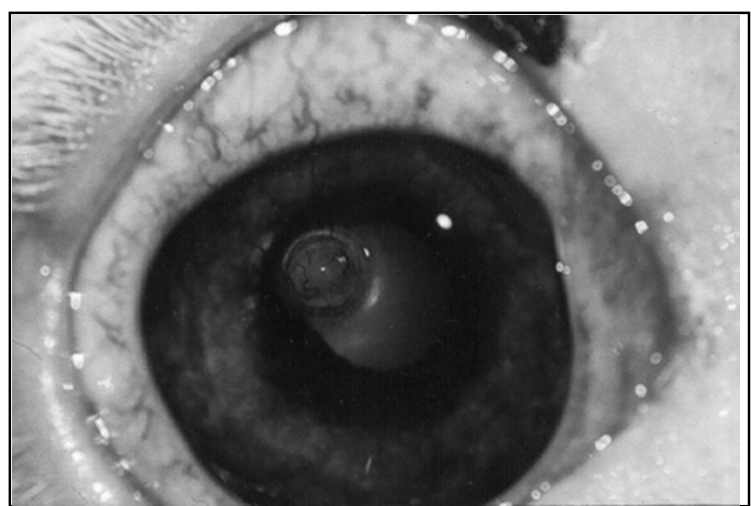

Figure 1 - Photography illustrating right cornea of a boxer breed dog with cystic formation of four millimeters of diameter and two high on the superotemporal quadrant. Note mild opacity and vascularization on and around the cyst (arrow).

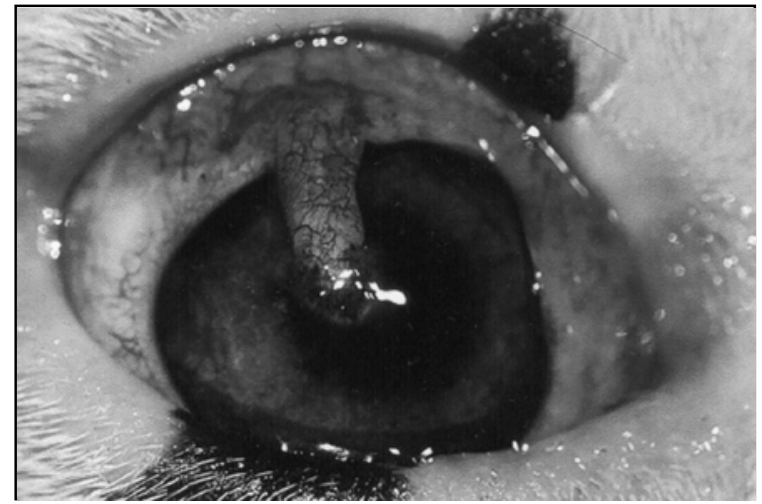

Figure 2 - Photography illustrating right cornea of a boxer breed dog with conjunctival pedicle graft forty days after surgery.

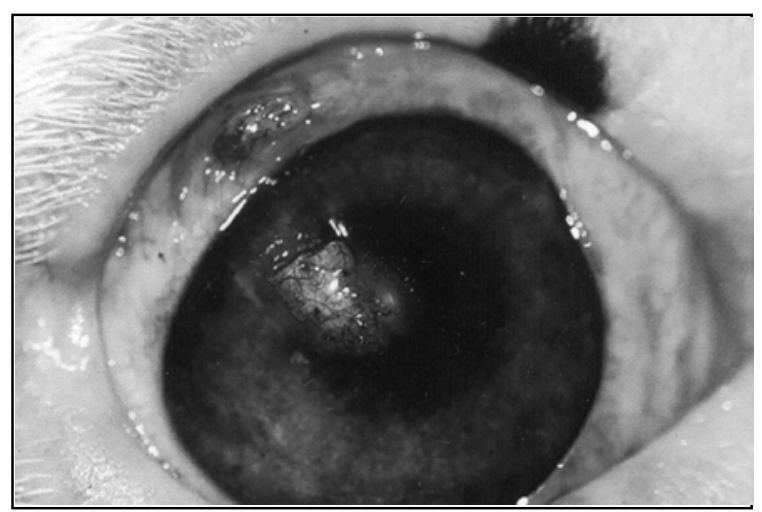

Figure 3 - Photography illustrating right cornea of a boxer breed dog with conjunctival graft four months after surgery. Note remodeling of the cornea and corneal vascularization.

(MAHMOOD \& AWAD, 1998), but most of the cases referred in dogs present a history of ocular lesions. According to this, the case referred here had a history of corneal ulceration at the same site of the cyst and had been treated by the same group of doctors.

The previous lesion was an indolent corneal ulcer treated by grade keratotomy and third eyelid flap. It may have lead the epithelial cells to be trapped within the superficial stroma during repair with consequent retaining of secretion and desquamated material. On the other hand, it could have been a consequence of the well known corneal distrophy of the boxer breed dogs in which a paucity of hemidesmossomes manifested as a degeneration of the epithelium occurs (GELATT \& SAMUELSON, 1982). In human beings, cystic formations in corneas presenting similar dystrophies have been referred (TABERY \& HOLM, 1987).

The healing process occurred as expected after the cystic remotion by keratectomy, according 
to the results previously reported by $\mathrm{KOCH}$ et $\boldsymbol{a l}$. (1974), SCHMIDT \& PRASSE (1976) and BEDFORD et al. (1990).

The clinical and microscopical characteristics of the Boxer epithelium dystrophy, as reported by GELATT \& SAMUELSON (1982), sustained the decision of performing a pedicle conjunctival graft, which was considered useful as no alteration was observed after the surgery.

\section{CONCLUSIONS}

The epithelial inclusion cysts have been considered an uncommon disease in dogs as only 21 cases have been reported. It has been acclaimed that superficial keratectomy is the treatment of choice. Based on the results of the case described here, the authors also suggest the use of conjunctival graft after superficial keratectomy in such cases when epithelial defects might be present. Besides, the use of antibiotic ointments as a prophylactic measure is considered advisable.

\section{SOURCES AND MANUFACTURERS}

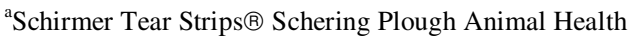

bonopen XL® Mentor Medical Sistems

‘Fluoresceína strips ${ }^{\circledR}$ Ophthalmo’s Fórmulas Oficinais Ltda.

${ }^{\mathrm{d} S}$ Slit lamp SL-14® Kowa Company Ltda

${ }^{\mathrm{e}}$ Tobrex ${ }^{\circledR}$ Labcon Alcon SA

\section{REFERENCES}

AIRAJHI, A.A., AIKHARASHI, S.A. Epithelial inclusion cysts following epikeratoplasty. Journal of Refractive Surgery, New Jersey, v.12, n.4, p.516-519, 1996.
BEDFORD, P.G.C. What is your diagnosis? A corneal epithelial inclusion cyst. Journal of Small Animal Practice, London, v.38, n.4, p.140,171, 1997.

BEDFORD, P.G.C., GRIERSON, I., McKECHNIE, N. M. Corneal epithelial inclusion cyst in the dog. Journal of Small Animal Practice, London, v.31, n.2, p.64-68, 1990.

FRANÇOIS, J. Recurrent dystrophic erosion of the corneal epithelium. Ophthalmologica, Basel, v.177, n.3, p.121-133, 1978.

GELATT, K.N., SAMUELSON, D.A. Recurrent corneal erosion and epithelial dystrophy in the boxer dog. Journal of the American Veterinary Medical Association, Schaumburg, v.18, p.453-460, 1982.

JESTER, J.V., VILLASENOR, R.A., MIYASHIRO, J. Epithelial inclusion cysts following radial keratotomy. Archives of Ophthalmology, Chicago, v.101, n.4, p.611-615, 1983.

KOCH, S.A., LANGLOSS, J.M., SCHMIDT, G. Corneal epithelial inclusion cyst in four dogs. Journal of the American Veterinary Medical Association, Schaumburg, v.164, p.1190-1191, 1974 .

MAHMOOD, M.A., AWAD, A. Congenital sclerocorneal epithelial cyst. American Journal of Ophthalmology, Chicago, v.126, n.5, p.740-741, 1998.

SCHMIDT, G., PRASSE, K.W. Corneal epithelial inclusion cyst associated with keratectomy in a dog. Journal of the American Veterinary Medical Association, Schaumburg, v.168, p.144, 1976.

TABERY, H.M., HOLM, O. Non-traumatic recurrent corneal erosion. A study based on sequential photomacrographic recordings. Acta Ophthalmologica, Copenhagen, v.65, n.5, p.521-528, 1987. 